\title{
REPORT ON THE REPATRIATION
}

\section{OF AFGHAN REFUGEES - 1992}

UNHCR - Islamabad

1 March 1993 
NATIONS UNIS

HAUT COMMISSARIAT

POUR LES REFUGIES
UNITED NATIONS

HIGH COMMISSIONER

FOR REFUGEES

P.O. Box 3232, Kabul (Tel: 24915)

1, Kish Alley, Tehran (Tel: 8017611-7)

P.O.Box 1263, Islamabad (Tel:212051-6)

Is l amabad

9 March 1993

\section{Repatriation to Afghanistan}

Please find herewith a copy of the 1992 report. This includes tentative projections for 1993, which should, of course, be used with great caution. Given the circumstances prevailing in Afghanistan, the report cannot pretend to be an authoritative summary of what happened in 1992, still less of what might happen this year.

The report incorporates information provided by many sources. Every visit or mission to or within Afghanistan has the potential to provide information on repatriation that can help monitor and improve the international community's humanitarian assistance to returnees and their home communities. We are most grateful to all those who provided such information in 1992, and should welcome still more in 1993.

Nicholas Morris

Nicholas Morris 


\section{TABLE OF CONTENTS}

Map of Afghanistan

Foreword

$\begin{array}{ll}\text { Introduction } & \mathbf{3}\end{array}$

Departures from Pakistan: A 1992 Summary 4

Relationship between Encashing Refugees \& Actual Return 6

Pakistan to Afghanistan: Destinations 7

$\begin{array}{ll}\text { Departures from Iran: A } 1992 \text { Summary } & 8\end{array}$

Iran to Afghanistan: Destinations 9

Conditions at Home 9

Assistance: A Beginning but not Enough $\quad 10$

$\begin{array}{ll}\text { Repatriation Grants } & 10\end{array}$

Assisted Transport 11

$\begin{array}{lr}\text { Assistance Inside Afghanistan } & 12\end{array}$

$\begin{array}{ll}\text { Coordination with Governments } & 13\end{array}$

Trends of Return $\quad 14$

1993 Projections 14

Graphs

Number of Encashments

Destinations by Passbook Encashment 7

Afghan Refugees in Pakistan: Origins \& Return 15 


\section{AFGHAN REFUGEES: ORIGINS}

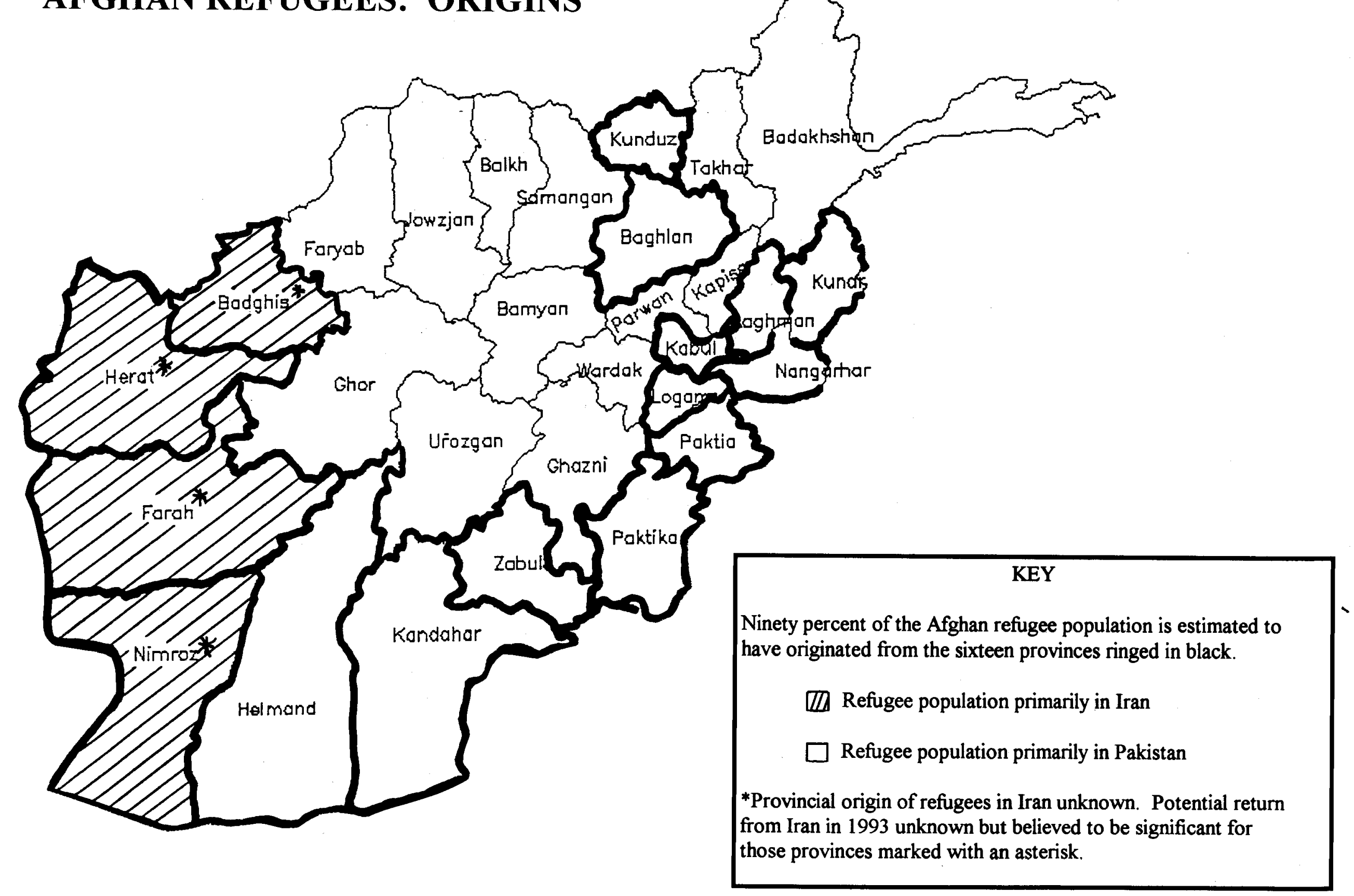




\section{Foreword}

Sources for this Repatriation Report include summaries of Notes for the File, Afghan Field Monitors' Reports, reports from UN and NGO missions to Afghanistan, and conversations with UNHCR field staff. Statistics presented in this report are obtained from the Repatriation Grant Program and the border monitoring done throughout 1992. For the sake of completeness, some information contained in earlier reports is repeated.

Projections given about possible trends of return during 1993 are based on information available to UNHCR in February 1993. The political situation inside Afghanistan as of this date is extremely fluid and very volatile. It is impossible to predict whether information about conditions affecting return today will remain relevant over the next six months.

A note of caution: statistics on repatriation must be used with care and a healthy degree of skepticism. Exceptions abound for every generalization offered. With the exception of the encashment figures, all numbers used in this report are approximations. Statistics about Afghanistan give order of magnitude information only and are informative for what they tell us about trends.

This report was prepared by UNHCR consultant Wendy Batson with UNHCR staff in Iran, Pakistan, and Afghanistan. 


\section{Introduction}

Fourteen years of armed conflict caused enormous displacement of the Afghan population, particularly from the heavily populated eastern provinces of the country. Up to six million Afghans, as many as one third of Afghanistan's 1978 population, are estimated to have fled, or been unable to return to, the country, with half of that total finding refuge in Pakistan and the other half in Iran. Another 800,000 to one million are believed to have been displaced by the fighting to the more remote, mountainous regions of the country or to the relative security of the country's few towns and cities.

Despite the final withdrawal of Soviet forces from Afghanistan in February 1989, the long-anticipated collapse of the Najibullah regime did not take place when predicted by most observers, and armed conflict between the Government and the mujahideen as well as inter-mujahideen struggle continued throughout 1989, 1990, and 1991. Although the war became less destructive of life and property (except in Kabul) than before 1989, the provinces from which the great majority of refugees came remained among the most hotly contested.

As early as the summer of 1989 , however, there were reports of refugees returning to Afghanistan to cultivate their fields and to rebuild their homes. The mujahideen had, by 1989 , consolidated their control of an estimated $80 \%$ of the rural areas of Afghanistan, leaving the Soviet-installed government in control of Kabul, the provincial capitals and the approach roads to Kabul. It was to these mujahideen-controlled areas that refugees began tentatively returning. Many of these early repatriates are believed to have returned to Pakistan with the onset of winter, thus availing themselves of the safety net of ration distributions and services available in the refugee villages. At the close of 1991, UNHCR estimated that at least 200,000 refugees had returned during the year, to join the 100,000 to 150,000 estimated to have returned during 1989 and 1990 .

With the fall of the Najibullah government in late April of 1992 , the long awaited mass repatriation finally began. The transfer of power from the old regime to a variety of mujahideen-led coalitions in the provincial centers of Afghanistan triggered an enormous movement of people into Afghanistan. Of the six million Afghans who had sought sanctuary in Iran and Pakistan, 1.5 million returned home by the close of 1992. In one week alone last summer, more than 100,000 people crossed the border. Riding in trucks piled high with their household possessions, livestock, the roof beams and window frames taken from their refugee village home, they carried with them as much as they could to assist in the difficult work of rebuilding a life back home. 


\section{Departures from Pakistan: A 1992 Summary}

The most reliable statistics on destinations of repatriating Afghans are available from the UNHCR/WFP sponsored Repatriation Grant Program. The great majority of refugee families in Pakistan are registered with the Government of Pakistan (GOP) and hold GOP/UNHCR ration books. When a family decides it is time to return home, the family head exchanges their ration book for a repatriation allowance of 3,300 rupees (about $\$ 130$ US) and 300 kilograms of wheat. When a returning refugee hands in his family's book, encashment clerks record his family's intended destination.

Refugees in Pakistan anticipated the political changes coming in April, and started encashing their ration books in ever greater numbers during the first quarter of 1992. Between January and the end of Ramazan in early April, just over 13,000 families returned their ration cards. During the same period a year earlier, only 3,000 families had encashed their cards.

With the collapse of the Najibullah regime in April, and the subsequent transfer of power from the previous authorities to new coalitions in the provincial centers, return increased dramatically. During the first half of 1992, almost half a million Afghans went home, more than were estimated to have returned during the previous three years combined. When repatriation from Pakistan reached its peak in July, over 100,000 returned in a single week, making the Afghan repatriation the largest and fastest exercise of its kind ever assisted by UNHCR. By the close of the year, 1,274,016 people, more than a third of the total refugee population believed to be in Pakistan at the beginning of the year, had received assistance through relinquishing 215,907 ration cards. 
UNHCR set up a total of fourteen encashment centers to handle the encashment grants, nine in NWFP and five in Balochistan. The wheat portion of the grant was dispensed from eight locations which were in close proximity to the encashment centers in NWFP and from three locations on the Pakistan-Afghanistan border in Balochistan.

As the numbers swelled to thousands a day in mid-summer, UNHCR mobilized every available staff person to keep the system functioning. Problems abounded: the encashment program was underfunded and the rapidly increasing demands on the system led to temporary shut downs because of lack of cash. Limited banking capacity and the difficulties encountered in transferring funds to the encashment centers also affected the program.

Most crucial, security considerations made it difficult or impossible to open up centers in key tribal areas of the North West Frontier Province, where tens of thousands of refugees live. Tribal territory residents were thus forced to travel considerable distances to encash, and their arrival at overworked centers in the settled territories exacerbated already tense situations. Some refugees came back numerous times before they were finally processed. Others gave up, discouraged from long days of waiting under an increasingly hot sun as the summer progressed, and sold their ration books to traders and other refugees at less than the card's total value.

Problems of supply also beset the distribution of the wheat. At its peak, the encashment program required three hundred metric tons of wheat per day, a demand which logistical bottlenecks made difficult to meet. At the end of July, the wheat deficit exceeded 10,000 metric tons in the North West Frontier Province and 2,000 metric tons in Balochistan. As demand dropped from the peak levels of mid-summer, this backlog was cleared.

Nonetheless, strained as the system often was by the unprecedented demands of mid-summer, over a million refugees returned to their home villages in the last three quarters of 1992 assisted by the repatriation grant program. And they made the trip into Afghanistan under conditions of relative security with few reported instances of theft or exorbitant taxation on the goods they carried. Refugees were allowed to transport their household effects, livestock and wheat for home consumption with minimal problems due to the close cooperation of the provincial authorities, who issued orders to the Frontier Corps and political agents to allow the free movement of returnee's household effects across the border. This cooperation was crucial to the ability of newly-repatriated Afghans to survive during the first difficult months back in their home villages, as few of the items required to start life anew are yet readily available inside Afghanistan.

UNHCR, with assistance from the Government of Pakistan, will open at least four new encashment locations in 1993, three in NWFP in or near the tribal agencies where tens of thousands of refugees still reside and one in the Punjab to serve the almost 150,000 people still living in the refugee village of Kot Chanda. WFP has sufficient tonnage of wheat available to ensure regular supply of wheat to encashing refugees. And 
staffing plans for a number of additional encashment clerks and supervisors to oversee the program which, depending upon the political situation inside Afghanistan, could benefit as many as another million returnees in 1993.

\section{Relationship between Encashing Refugees \& Actual Return}

UNHCR staff cannot be certain how many of those who encashed actually returned to Afghanistan. Some percentage of refugees were undoubtedly families with several ration cards who chose to encash one or more because of some unexpected need for cash or to fund their move to one of the larger cities in Pakistan. UNHCR monitoring at the major border crossings between Afghanistan and Pakistan, however, suggests a close relationship between the levels of encashment and actual return to Afghanistan.

Although it is not possible to monitor continuously all the important border crossings, UNHCR staff have been stationed during daylight hours at the primary border crossings between Pakistan and Afghanistan. More remote crossing points were not monitored. Monitors record only clearly identifiable family groups, i.e., they count trucks carrying families who have brought all their household possessions with them. Partial family return, heads of household returning to assess the situation in their village or begin the preliminary work of putting up a dwelling are not counted. Nor can the monitors observe the many refugees who arrive at the borders before daylight to ensure that they reach their village in Afghanistan before nightfall. Thus the figures obtained are partial and do not show the true volume of refugee return to Afghanistan during 1992.

Nonetheless, almost 900,000 people (seventy percent of encashment) were observed crossing into Afghanistan during 1992. Correlation between encashment and observed border crossing was particularly high for Nangarhar, the province which took in more refugees than any other during the year. A total of 300,156 people gave districts in Nangarhar as their destination when they encashed, while 269,709 people (90\% of encashment for Nangarhar) gave districts in that province as their destination when questioned at the border as they left.

UNHCR program staff responsible for running assistance programs in the refugee villages in Pakistan monitored the flow of people from these villages to the border, noting the complete desertion of large sections of refugee villages throughout Pakistan. Departing families often removed the roof beams and window frames of their homes in Pakistan and took them back to their villages in Afghanistan to use in the first, small structures which they erected upon their return, an indication of a new willingness to sever all ties with the support system in Pakistan. 


\section{Pakistan to Afghanistan: Destinations}

Out of the twenty nine provinces listed as destinations by encashing refugees, some $68 \%$ percent of the year's repatriates returned to the provinces bordering Pakistan, from which an estimated $85 \%$ of the Afghan refugee community in Pakistan originate. Ninety percent of the refugees who relinquished their ration cards since the July 1990 commencement of the program cited one of the twelve provinces listed below as their intended destination. For comparative purposes, and to give some sense of the magnitude of the shift of people across the border during 1992, encashed passbook totals have been given as of 2 April 1992 (before the collapse of the Najibullah government) and as of 31 December 1992.

\begin{tabular}{|c|c|c|}
\hline Provinces: & Tassbooks encrs hed & $\begin{array}{l}\text { I ass bools encashed? } \\
\text { as of } 31 \text { Deceminer } 1992\end{array}$ \\
\hline Nangarhar & 5,197 & 51,248 \\
\hline Paktia & 2,675 & 38,058 \\
\hline Kandahar & 15,545 & 32,835 \\
\hline Kunar & 3,291 & 26,758 \\
\hline Kunduz & 8,961 & 22,907 \\
\hline Baghlan & 6,781 & 16,822 \\
\hline Helmand & 5,965 & 15,605 \\
\hline Kabul & 771 & 10,761 \\
\hline Laghman & 710 & 8,079 \\
\hline Logar & 630 & 7,866 \\
\hline Zabul & 1,875 & 7,843 \\
\hline Jowzjan & 614 & 3,627 \\
\hline
\end{tabular}

Although return has been large-scale to all the eastern provinces bordering Pakistan and to the two northern provinces of Kunduz and Baghlan, return during the peak months of June, July and August was most significant to those districts in the eastern provinces to which repatriation had begun before the collapse of the previous regime. Long before April 1992, relief workers were reporting that Afghans from areas close to the border were moving into Afghanistan, often for only part of the year, to begin cultivating crops again.

In the first three months of 1992, partial family return to Paktia and Nangarhar was taking place, whereby heads of household, accompanied by older sons, returned to begin reconstructing some kind of shelter, rebuilding irrigation canals and planting crops. When the Najibullah government fell, reclamation activities were already far enough advanced in these districts to allow the very rapid integration of tens of thousands of returnees. It is to 
the areas where such preliminary activities were already well advanced that the vast majority of refugees went after April.

Return has also been significant to those areas of the eastern and northern provinces which were previously controlled by the former government. This newlyaccessible territory included all of central Nangarhar, western Paktia, the city and surrounding suburbs of Kandahar, and the provincial centers of Kunduz and Baghlan as well as the heavily-populated valleys which lie, in many instances, roughly parallel to the approach roads to Kabul.

\section{Departures from Iran: A 1992 Summary}

The Government of the Islamic Republic of Iran estimates that some 300,000 individuals crossed the border into Afghanistan in 1992. It is not known what percentage of these represented permanent repatriates, as the above figure includes traders, visitors and others who were not repatriating. At the peak of the return in July, up to 2,500 people were thought to be returning daily. By mid-August, however, the rate of return fell to about 1,000 to 1,500 individuals a day, tailing off still further with the approach of winter.

On 1 December 1992, UNHCR, in collaboration with the Government and WFP, began an assistance program for Afghans in Iran who wished to return permanently to Afghanistan. The assistance given includes the equivalent of \$25 US in cash and fifty kilos of wheat to each individual and a $3 \times 4$ meter plastic sheet for each family group. The cash and wheat component were given to every member of the family, including children, provided that they had a one-way Laissez Passer issued by the Iranian Government and had declared themselves as refugees intent upon returning to Afghanistan for permanent settlement The amount given is roughly equivalent to the family grant currently issued in Pakistan as part of the Repatriation Grant Program.

The program began in Khorasan Province at the Dogharoon Border Exit Station, the crossing used primarily by Afghans returning to or through Herat. During the first month in operation, 6,926 repatriates received UNHCR/WFP assistance packages. The average daily returns totaled 243 individuals a day, the majority traveling in family groups.

Expansion of the program will include the establishment of other exit stations in Khorasan and Sistan-Balochistan provinces as well as the setting up of in-country transit centers in Tehran, Isfahan, Kerman, and either Birjand or Mashad. The International Organization for Migration (IOM) and UNHCR will also provide transport assistance from transit centers in Iran to the border and, when necessary, to points inside Afghanistan. Upon establishment of an efficient in-country transportation network, foreseen by late March 1993, the cash grant will be reduced accordingly. 


\section{Iran to Afghanistan: Destinations}

UNHCR did not monitor crossing points on the Iran-Afghanistan border during 1992 except occasionally at Islam Qala, the primary entrance point for people traveling to or through Herat. Not all refugees crossing at Islam Qala were interviewed. Approximately $65 \%$ of those who were interviewed by UNHCR gave Herat Province as their destination. Twenty-five percent gave destinations divided evenly between Faryab, Badghis, Ghor, Farah and Mazar provinces while the remaining ten percent dispersed throughout the rest of the country.

With the establishment of the repatriation grant assistance program for Afghan refugees in Iran, UNHCR began a more systematic collection of statistics. Of the almost 7,000 Afghans receiving repatriation grants at Dogharoon in December, 95\% were returning to Herat. The remaining five percent went back to Ghor, Faryab, Badghis, Farah and the northern provinces.

It is assumed that the expansion of the repatriation grant assistance program for Afghans to other points in Khorasan and Sistan-Balochistan will support the anticipated increase in returnees wishing to return to Nimroz, Farah, and the Hazarajat.

\section{Conditions at Home}

Afghans are returning to a country ravaged by fourteen years of civil war which has left houses bombed or collapsed, roads and irrigation systems deteriorated to the point of uselessness, and fields so long grown over that their reclamation may well take years. The scale of the destruction is enormous, and in many key areas the presence of mines makes return even more difficult. A series of repatriation surveys prepared for UNHCR by the Swedish Committee for Afghanistan during 1992 identified destruction of houses as the initial, overwhelming concern of returning refugees. Destruction of irrigation systems, food shortages, and the scarcity of health and education facilities also ranked high as major concerns. Unemployment preoccupies those Afghans who returned to towns like Jalalabad and Kandahar, and the landless refugees dependent upon a prosperous rural community for their livelihood.

Repatriates interviewed inside Afghanistan during the summer and early fall did not rank mines as a major problem, a fact which can be interpreted as an indication of the self-selection involved in return to specific areas. If mines are present in large concentrations, return is marginal or does not occur at all, and Afghans from such areas interviewed in refugee villages in Pakistan cite the presence of mines in their home areas as a major reason for not returning. Statistics available from the International Committee of the Red Cross (ICRC) hospitals for the War Wounded show a marked and tragic increase in mine injuries and fatalities during the summer and fall of 1992. Afghans brought into the ICRC hospitals for treatment of mine injuries were overwhelmingly recent returnees to their home villages. 
A clear evolution of concerns is apparent when interviewing returnees over the past year. Although house construction or repair is a major preoccupation of all refugees interviewed, when talking with refugees who have been back longer than six months, greater emphasis is given to problems of irrigation repair, unemployment and school and health clinic construction. This shift in emphasis probably reflects the fact that many returning families have at least partially solved their housing problems within the first six months of return, allowing them to shift their concerns to problems which are beyond any one family's ability to solve on their own.

\section{Assistance: A Beginning but Not Enough}

Although assistance to the Afghan community has fallen far short of the amounts envisioned in early planning after the Geneva Accords in 1989, the limited degree of support from the international community has not deterred hundreds of thousands of Afghans from choosing to return home. Lack of funds, limited absorptive capacity, logistical bottlenecks, the absence of infrastructures and, most crucially, continuing political instability, have made the delivery of assistance inside Afghanistan difficult. UN agencies and NGOs have attempted, however, to ameliorate conditions in some of the most war-devastated and refugee impacted areas of the country.

\section{Repatriation Grants}

Central to UNHCR assistance to returning refugees has been the repatriation grant program described above. Generous support from the international community provided the $\$ 28.5$ million dollars in cash and the 64,700 metric tons of wheat required to enable UNHCR and WFP to provide each registered family who encashed in Pakistan in 1992 with wheat and cash, and allowed the start up of direct assistance in Iran..

An estimated $75 \%$ of the refugee community in Pakistan live within one day's full travel from their villages in Afghanistan. The approximately $\$ 130$ US provided by the grant is sufficient to allow the vast majority of refugees to arrange their own transport home. Transportation costs to the eastern provinces are such that most families arrive home with some cash left over to assist them in their first attempts at reintegration. The 300 kilos of wheat provided is sufficient to tide an average sized family through the first difficult months of return.

Observers traveling in Nangarhar and Paktia during the summer of 1992 commented on the rapidly expanding bazaars in communities across both provinces. The very presence of such large numbers of returnees has created a demand for lumber, scrap metal, household implements, agricultural goods and so forth. Although the encashment grant averages out to approximately $\$ 20$ per person entitled, the huge numbers of refugees moving into Nangarhar and Paktia have assisted in the creation of an embryonic market system. The 47,000 ration cards turned in by refugees from Nangarhar represents a total cash value of just over $\$ 6,000,000$, approximately half of which was estimated to 
have been used to hire transport home. The remaining $\$ 3,000,000$ has enabled refugees to purchase crucial goods needed to begin life anew. Although many of these purchases were made in Pakistan, the enormously increased presence of the returnees has also contributed to the funding of the newly emerging economy of Nangarhar.

\section{Assisted Transport}

Refugees living in Pakistan who came from areas of Afghanistan north of Kabul were faced with much higher transport costs that those refugees originating from provinces bordering Pakistan. To redress this imbalance, UNHCR signed an agreement with the International Organization for Migration (IOM) in June under which IOM assists in the transport of families from the north. The mechanisms worked out allowed these refugees to organize their own transport home through negotiations with private truckers. IOM, upon certifying that the family had arrived at its northern destination, defrayed $60 \%$ of the cost of the trip. By utilizing private transportation arrangements, refugees from the north were able to make the trip from their refugee villages to their home areas without off loading at transit centers en route.

IOM began the first assisted movements of refugees to the northern provinces from Peshawar in early July. At the close of 1992, 21,488 individuals had returned home under the program, 17,792 from Pakistan and 3,626 from Iran (assisted from Herat onwards). Of those assisted, seventy percent departed from the refugee camps of the North West Frontier Province. Just over half of the people who benefited returned to key districts in Baghlan and Kunduz while most of the remainder went to Balkh and Faryab.

At the close of the year, IOM, in cooperation with UNHCR and Handicap International, arranged the transport of a small group of paraplegic and quadriplegic Afghans who requested specialized assistance in returning home from Pakistan. Although all were from nearby provinces, their condition left them unable to travel home in the trucks usually rented for such purposes. It is envisioned that such special arrangements will continue to be made for the handicapped if and when such refugees request assistance.

\section{Assistance Inside Afghanistan}

Assistance to returning refugees was provided cross-border from Pakistan throughout 1992. A total of US $\$ 1.9$ was committed to facilitate the permanent return of Afghan refugees living in Pakistan through the provision of relief goods and infrastructural support in their home areas in Afghanistan. The focus of this assistance was on areas where refugee families were unable to return permanently in spite of the fact that they considered the security situation in their village to be satisfactory. Some of the refugees benefiting from this program were unregistered and thus not eligible for the repatriation grant; others were so poor that even with the grant they were unable to cover their initial re-integration costs.

These cross-border projects were initiated by the refugees themselves or by the communities inside Afghanistan faced with the problems caused by the return of refugees or the internally displaced. The rehabilitation activities financed under this project ranged 
from the provision of tarpaulins, water pumps, hand tools, the digging of shallow wells, the cleaning of small but crucial canals and kareezs to the rehabilitation of the Dand drainage system, a project which should reduce the flooding of key areas of Kandahar during the spring rains.

As the year progressed, and security conditions improved, UNHCR was able to commence with the organization of sub-offices within Afghanistan. As these offices became functional, cross-border work became their responsibility.

UNHCR opened sub-offices in Herat, Kandahar, Jalalabad and Mazar-i-Sharif during 1992 in order to meet protection and immediate rehabilitation needs more effectively. UNHCR assistance inside Afghanistan has been structured around Quick Impact Projects (QIPS), small, rapid-to-implement projects which require one-time investments designed to address urgent needs at the community level. A basic premise of the work in Afghanistan is that assistance will be provided to communities on the basis of needs with no distinction made between returning refugees, the internally displaced and those who remained behind. QIPs designed for Afghanistan focus on three sectors: housing/shelter; drinkable water; and rehabilitation of irrigation systems. Rehabilitation of secondary roads leading to returnees' home areas was also undertaken on a small scale.

Each field office was initially budgeted for up to half a million dollars to begin work in sectors identified above. Immediate assistance was provided through the provision of emergency shelter materials such as tents, blankets, plastic sheeting and tarpaulins, the latter which were used for a variety of purposes from temporary roofs over newly-constructed walls to ground cloths for children attending newly-organized schools under trees. QIPs were designed to provide immediate cash or WFP wheat to support a family while they rebuilt their home, to provide employment through paying for the cleaning or reconstruction of drains and irrigation canals, and to provision farmers with the hand tools needed to begin reclamation of their fields. Other such projects have included the digging of shallow wells and the repair of small bridges and culverts.

UNHCR works in close cooperation with other UN agencies and NGOs in eastern Afghanistan, leaving main responsibility for rehabilitation and development activities to agencies technically qualified to carry out such work. In western and northern Afghanistan, where very few NGOs are yet present, UNHCR implements rehabilitation projects directly.

Key to the rapid implementation of the projects described above was the ability of the World Food Program to supply the wheat needed to key areas of return. Wheat delivery has increased substantially since 1989, when 7,500 metric tons were provided for cross-border work. In 1992, WFP provided close to 40,000 metric tons of wheat, almost all of it cross-border from Pakistan. Only twelve percent was used in emergency feeding programs; the remainder was utilized by food-for-work projects, most of it in areas of high refugee return. 
The complicated and changing security environment in Afghanistan calls for a high degree of flexibility in the allocation of funds. UNHCR has used its limited resources not only to assist communities affected by the return of tens of thousands of refugees from Pakistan and Iran, but has also, in cooperation with a number of NGOs and the other members of the UN family, assisted the newly-created internally displaced, driven out of Kabul by the resumption of fighting in August. It is estimated that as many as half a million recently internally-displaced Afghans require assistance, especially in the provision of emergency shelter. This is a population which may well continue to grow if fighting in Kabul is not halted.

\section{Coordination with Governments}

In May agreement in principle was reached with the governments concerned on the establishment of two tripartite repatriation commissions, comprising representatives of the Governments of Afghanistan, Iran (one commission) and Pakistan (the other commission), and of UNHCR. Such commissions have proved an effective means of ensuring coordination and resolving problems in other voluntary repatriation movements. A draft text was prepared by UNHCR and extensively discussed with the governments. Agreement was reached on the text and one agreement was signed in Tehran on 31 October 1992. The other is expected to be signed in Islamabad shortly.

Both texts are identical. The principal objective of each commission "shall be to facilitate the safe, orderly and voluntary repatriation of Afghan refugees and their successful reintegration in Afghanistan." The text sets out the basic principles to be respected as well as the measures required to achieve the objective. The first meetings of each commission are expected to take place as soon as practical arrangements can be made. 


\section{Trends of Return}

Although return to Afghanistan during 1992 was unprecedented in scale, over 1.5 million registered Afghans remained in Pakistan, the majority of whom are assisted in 190 refugee villages. In addition, the Government of Pakistan estimates that there are as many as 500,000 un-registered refugees scattered throughout the country. Although the care and maintenance programs have been scaled down to reflect the reduced population, UNHCR and WFP, in cooperation with the Government of Pakistan, will continue to assist registered refugees during 1993.

As many as 2.5 million Afghans still live in Iran. The Afghans in Iran are widely dispersed. Nearly $60 \%$ live in the three border provinces of Khorasan, Sistan-Balochistan, and Kerman. Twenty percent are believed to be in Tehran while the remainder are scattered throughout the rest of the country.

Detailed and comprehensive information on the origins and socio-economic status of the Afghan refugees in Iran is not available, making it difficult to estimate trends of return to particular areas of Afghanistan. Surveys done by the Government, however, found that some $80 \%$ of the refugee population is male, $37 \%$ of whom are between the ages of $20-29$. The Government estimates that nearly all of these men are either unmarried or have left their families in Afghanistan. They work in construction and as agricultural laborers and their location in Iran reflects the demands of the labor market. As many as $20 \%$ of the Afghan refugee population were in Iran before 1978 .

Thirty-five percent of the Afghan refugees in Iran are believed to be of Pashtu origin while twenty-seven percent are Tajiks and twenty percent are Hazaras.

Government officials in Iran point out that the common tie between almost all of the Afghans in Iran is language - the vast majority speak Dari. A third to a half of the refugee population in Iran are believed to be from the western provinces of Herat, Farah, Badghis, and Nimroz. Up to twenty percent are estimated to come from the Hazarajat, with the largest group originating from the western districts of Ghazni. Significant numbers also came from the northern provinces.

\section{Projections}

It is not known how many of the Afghans remaining in Pakistan and Iran will choose to return home during 1993. Even with the change in government in April, security in the area of origin still remains the principal factor in each refugee family's decision to go home. To date, Afghan leaders have been unable to coalesce around a central government respected by all parties, and thus local conditions continue to dictate patterns of return. It is particularly difficult to predict Afghanistan's political future when the causes of recent intense conflict in Kabul remain unresolved.

Yet even doring the heaviest days of fighting in August, return to secure areas of the country continued as others fled to Pakistan or the north. Thus it is likely that significant numbers of the refugees remaining in Iran and Pakistan will continue to return 
home if their village is quiet notwithstanding instability elsewhere. Estimating numbers is difficult but information gathered from a variety of sources suggests the following possibilities for return during 1993.

Almost $90 \%$ of the total refugee population in Pakistan in 1988 came from the provinces listed on the chart below. The patterned white bars followed by numbers estimate the refugee population in Pakistan in 1988; black bars estimate the total number of returnees to each province by the end of 1992.

\section{AFGHAN REFUGEES IN PAKISTAN: ORIGINS \& RETURN}

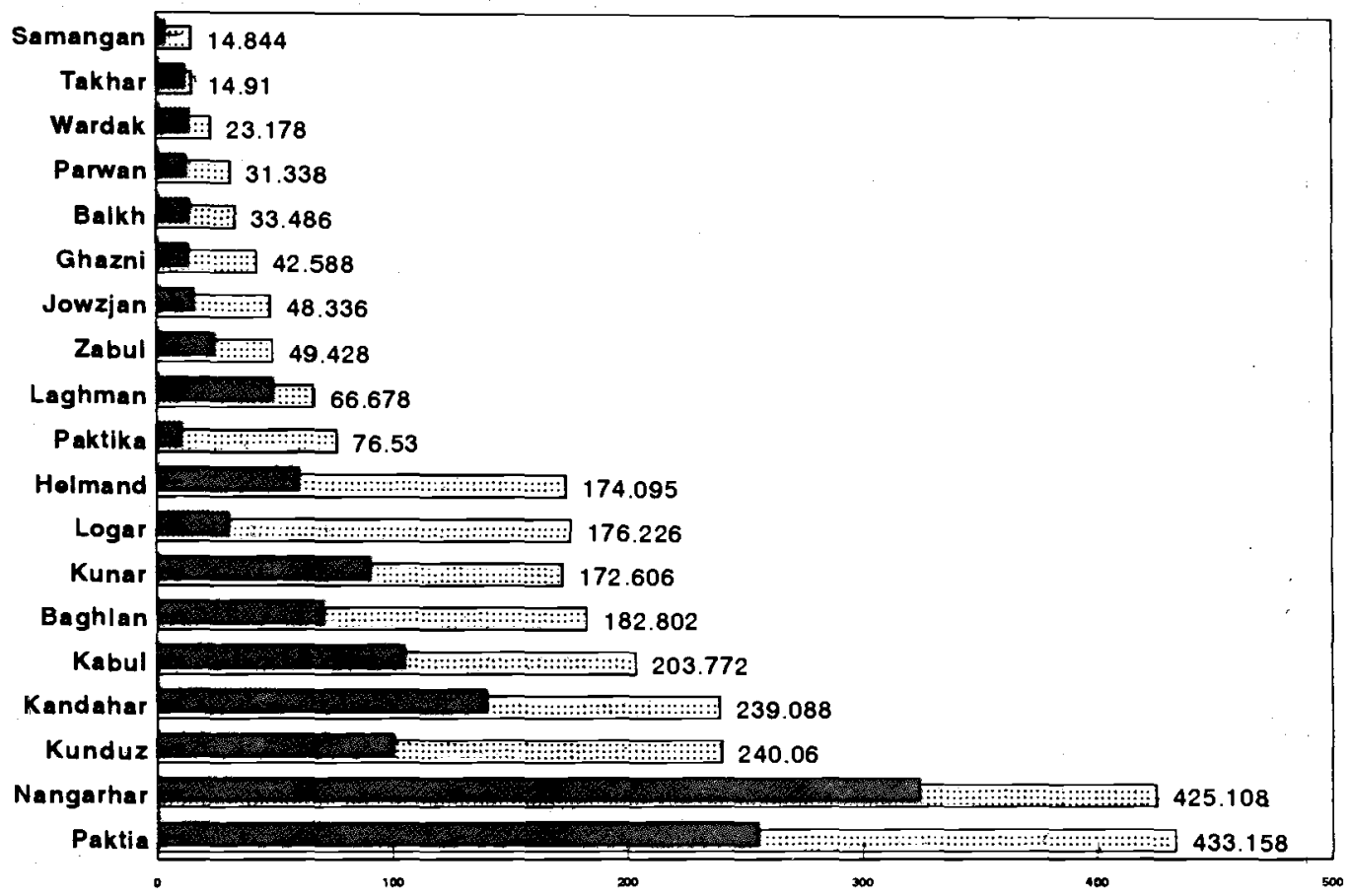

\section{Return To Date Total Outflow}

Information on the provincial origin of refugees used in this chart was taken from UNHCR's 1988 origin survey. Estimates on return are extrapolated from the origin survey, the repatriation grant program and the 1992 border monitoring reports.

The largest group of refugees still in Pakistan originates from Sayed Karam, Gardez and Zormat, the three most populous districts of Western Paktia. Refugees from these districts interviewed in refugee camps this winter continue to state their intention to return to Gardez and Zormat; former residents of Sayed Karam are less optimistic, fearing the wide-spread presence of mines and continuing political instability. 
Return is also expected to continue, albeit more slowly than in 1992, to eastern Paktia and to Nangarhar, areas to which an estimated $80 \%$ of the original population have already gone back. The widespread presence of mines in what was formally the security perimeters of Jalalabad and Khost will inhibit return unless considerably more assistance in demining is forthcoming. Others from these areas cite family poverty and poor employment prospects as the prime constraint.

Access roads to Logar remain insecure and circuitous, as the direct route is closed off by hostilities in Kabul. This will make transportation of both goods and people expensive and dangerous; thus large-scale return to Logar, particularly to the district of Mohammed Agra, is currently unlikely.

Return to Kabul remains very unlikely unless a lasting peace accord is reached before summer. It is unknown how many of the 100,000 people who returned to Kabul during the summer were forced to flee again with the resumption of hostilities in August. Continued insecurity in Kabul City affects return to surrounding districts in Kabul Province and to much of Logar, as both populations were to a large extent dependent on access to markets in Kabul for their economic survival.

Refugees in Bajour and Dir who originate from Kunar are expected to continue to move back home after Eid ul-Fitr and the opening of the road over the Nawa Pass to heavy traffic. Much preliminary reclamation took place late last summer and early fall, and unless political struggles over control of the province break out again, it is anticipated that return to Kunar will continue throughout the primary months of repatriation this year.

Return to Paktika is expected to much larger this year than last. Refugees interviewed over the winter have stated their intention of returning after Eid. Partial family or head of household return began late in the summer of 1992 to the key districts from which most of this province's refugees originate late in the summer of 1992. This group has begun the critical initial work of reconstruction, and many more families anticipate joining the earlier returnees sometime this spring.

For refugees from the southern provinces of Helmand and Kandahar, circumstances vary greatly. In a shift from past patterns, Helmand is more politically stable than in any other period during the past year. Continued conflict during the primary months of return in 1992 kept repatriation to Helmand at low levels compared with other provinces. Although tension remains high in Girishk, conditions in the provincial capital of Lashkar Gah and in the populous agricultural areas along the river in southern Helmand have encouraged refugees still in Balochistan to contemplate return after Eid.

Refugees from Kandahar express considerable uncertainty about returning for a variety of reasons. Key inhibiting factors are the lack of a confidence in the political stability in Kandahar City and surrounding environs and the presence of mines in the key agricultural areas of Dand, a district to which large numbers of refugees have not yet returned. Damage to irrigation systems is extensive in Kandahar, and, unlike in many 
other areas of Afghanistan, the systems are complex and interconnected, making smallscale/low cost repairs difficult.

Returns from Iran, which would probably be largely to the west, are also hard to predict. The extent of continued employment opportunities in Iran will determine the decisions of many Afghans. The majority of the Afghans in Iran come from areas where little has yet been done in start redressing the effects of years of conflict. Continuing instability and insecurity in Afghanistan is, of course, a major consideration for all Afghans contemplating repatriation. But with the expansion of both direct assistance to returnees from Iran and assistance to their home communities, a significantly higher level of repatriation than in 1992 is expected.

Return to the north from both Iran and Pakistan, and especially to the key provinces of Kunduz and Baghlan, is impossible to predict. Refugees express considerable confusion and uncertainty about political conditions in their home areas. Fighting in Kabul intensifies their fears, as the more direct and inexpensive return routes become either closed or too dangerous to contemplate using. Ethnic divisions and shifting alliances in Kunduz also make large-scale return unlikely unless the political situation stabilizes.

In the absence of conflict, the single biggest inhibitor to return remains the degree of destruction in any given area. Although Afghans have shown great resourcefulness and considerable willingness to tackle their problems irrespective of international assistance, some reconstruction needs in key areas of potential return is simply beyond the ability of families to undertake on their own. Thus, for example, key districts around Kandahar City and Jalalabad remain almost empty because a large intake or canal is destroyed or because of the presence of mines.

For the foreseeable future, economic, political, ethnic and religious considerations will continue to affect each refugee family's decision as to whether or not and when they should return home. But it is surely the absence of a lasting peace that today looms largest in the minds of Afghan refugees. Those whose homes are once again a theatre for war cannot return in safety. And the absence of peace makes much more difficult the lives of those who have returned, and the task of those who seek to help them. 
